\title{
Association between low levels of 1,25-dihydroxyvitamin D and breast cancer risk
}

\author{
Esther C Janowsky ${ }^{1, *}$, Gayle E Lester ${ }^{2}$, Clarice R Weinberg ${ }^{3}$, Robert C Millikan ${ }^{1}$, \\ Joellen M Schildkraut ${ }^{4}$, Peter A Garrett ${ }^{1}$ and Barbara S Hulka ${ }^{1}$ \\ 'Department of Epidemiology, University of North Carolina at Chapel Hill, Chapel Hill, NC 27599, USA: \\ ${ }^{2}$ Department of Orthopedic Surgery, University of North Carolina at Chapel Hill, Chapel Hill, NC 27599, USA: \\ ${ }^{3}$ National Institute of Environmental Health Sciences, Research Triangle Park, NC 27709, USA: ${ }^{4}$ Office of Cancer \\ Prevention and Control, Duke University Medical Center, Durham, NC 27710, USA
}

Submitted 25 July 1998: Accepted 1 February 1999

\begin{abstract}
Objective: To determine if blood levels of 25-hydroxyvitamin D (25-D) or its active metabolite, 1,25-dihydroxyvitamin D (1,25-D), are lower in women at the time of first diagnosis of breast cancer than in comparable women without breast cancer.

Design: This was a clinic-based case-control study with controls frequency-matched to cases on race, age, clinic and month of blood drawing.

Setting: University-based breast referral clinics.

Subjects: One hundred and fifty-six women with histologically documented adenocarcinoma of the breast and 184 breast clinic controls.

Results: There were significant mean differences in 1,25-D levels $\left(\mathrm{pmol} \mathrm{ml}^{-1}\right)$ between breast cancer cases and controls; white cases had lower 1,25-D levels than white controls (mean difference \pm SE: $-11.08 \pm 0.76$ ), and black cases had higher 1,25-D levels than black controls (mean difference \pm SE: $4.54 \pm 2.14$ ), although the number of black women in the study was small. After adjustment for age, assay batch, month of blood draw, clinic and sample storage time, the odds ratio $95 \%$ confidence interval, CI) for lowest relative to highest quartile was 5.2 (95\% CI 2.1, 12.8) for white cases and controls. The association in white women was stronger in women above the median age of 54 than in younger women, 4.7 (95\% CI 2.1, 10.2) vs. 1.5 (95\% CI $0.7,3.0)$. There were no case-control differences in 25-D levels in either group.

Conclusions: These data are consistent with a protective effect of 1,25-D for breast cancer in white women.
\end{abstract}

The classic function of $1,25-\mathrm{D}$, the hormonally active form of vitamin $\mathrm{D}$, is the maintenance of normal levels of calcium and phosphorus in the blood. However, recent work has defined a previously unsuspected involvement of vitamin $\mathrm{D}$ in cellular growth and differentiation ${ }^{1}$. This recognition has fostered an interest in the investigation of a possible role for vitamin $\mathrm{D}$ in carcinogenesis ${ }^{2,3}$. Ecological studies support a relationship between low levels of sunlight exposure and incidence of breast cancer (USSR) ${ }^{4,5}$ and mortality from breast cancer (USA) ${ }^{6,7}$. A single case-control study in Canada, however, failed to demonstrate an association between low consumption of vitamin $\mathrm{D}$, as determined by dietary history, and breast cancer in women above and below the age of 50 years ${ }^{8}$. Serum studies on these women were not available.

The role played by vitamin $\mathrm{D}$ in carcinogenesis is unclear. 1,25-D treatment both inhibits growth and promotes differentiation in human breast adenocarcinoma cells in culture irrespective of their sex-steroid dependence $^{9,10}$. Further, 1,25-D induces apoptosis in some cultured breast cancer cells ${ }^{11,12}$. Finally, vitamin D has an immunoregulatory function ${ }^{13}$.

The effects of 1,25-D are regulated primarily by an intracellular vitamin $\mathrm{D}$ receptor (VDR) in a manner analogous to other steroid hormones ${ }^{14}$, although receptor-independent mechanisms may also be impor$\tan t^{15}$. High affinity VDRs have been reported in breast cancer cell lines with and without oestrogen receptors ${ }^{10,16}$.

There is little clinical information on the effect of early stage breast cancer on blood levels of the vitamin $\mathrm{D}$ metabolites. One study indicates that early stage invasive breast cancer itself does not affect blood levels of $1,25-\mathrm{D}^{17}$. Nevertheless, it is recognized that patients with advanced disease and hypercalcaemia of malignancy often have low circulating concentrations of 1,25-D and parathyroid hormone (PTH) ${ }^{18,19}$.

Racial differences in both breast cancer and vitamin D metabolism have been described. Black and Hispanic 
women with breast cancer have lower overall 5-year survival rates than white women, even when differences in stage at diagnosis and differences in treatment are taken into account ${ }^{20}$. Studies report racial differences in vitamin $\mathrm{D}$ metabolism and utilization for both blacks and Hispanics compared to whites ${ }^{21-24}$, with lower levels of 25-D and higher levels of 1,25-D and PTH in minority women. It is unclear what the mechanism for these differences may be; some investigators interpret the low levels of 25-D as being due to a lower production of vitamin D in more heavily pigmented $\operatorname{skin}^{25,26}$.

There is one published study to date in which no relationship was found between prediagnostic 1,25-D levels and breast cancer ${ }^{27}$. However, the serum levels of vitamin $\mathrm{D}$ were obtained an average of 15 years before the clinical diagnosis of cancer. The authors noted that they did not adequately address a possible protective effect of serum vitamin $\mathrm{D}$ at a time more proximal to clinically evident breast cancer ${ }^{27}$. Our study was designed to determine whether blood levels of the active metabolite of vitamin $\mathrm{D}, 1,25-\mathrm{D}$, are lower in black and white women at the time of first diagnosis of breast cancer than in comparable women without breast cancer. A second purpose was to determine whether levels of the precursor hormone, 25-D, are related to breast cancer risk, and to describe the relationship between the two vitamin $\mathrm{D}$ metabolites among these study subjects.

\section{Methods}

\section{Source population}

Blood samples and interview data were available on 633 subjects who had participated in a previous study of genetic determinants of breast cancer ${ }^{28}$. The current study was approved by the Committee on the Protection of the Rights of Human Subjects of the School of Medicine of the University of Carolina, Chapel Hill. Women with biopsy documented, incident breast cancer (less than 6 months post-diagnosis, no chemotherapy) had been recruited from the Duke University Multidisciplinary Breast Clinic, the University of North Carolina Hospital Breast Clinic and the Durham Regional Hospital Clinic, over a 15-month period from April 1990 through June 1991. More than $90 \%$ of cases were enrolled into the study within 2 weeks of diagnosis, often prior to the biopsy providing a definitive diagnosis of breast cancer. Control group subjects came from these same clinics, but did not have breast cancer. Each control answered the questionnaire, donated blood, and was found to be free of breast cancer. The study was restricted to females aged 21 or older. Women were excluded from the study if there was a current or past diagnosis of epithelial hyperplasia, with or without atypia. Controls were frequency-matched to cases on age (within 3 years), race, clinic and month of blood drawing. A second control group came from two general medical clinics at the University of North Carolina and had non-breastrelated complaints. These women were matched to cases on age (within 3 years) and race and were enrolled in the study during an 8-week period from mid-April to mid-June 1991.

There were 215 women with breast cancer; 51 were excluded because they had been diagnosed more than 6 months before the beginning of study enrollment. One woman with phylloides tumour was excluded and blood samples for seven women could not be located or were not of sufficient quantity for assay, leaving blood samples from 156 subjects with adenocarcinoma of the breast for analysis in the case group. There were samples from 215 control women in the breast referral clinics; 30 of these subjects were excluded from the study because they did not meet the frequencymatching criteria, and one blood sample could not be located, leaving samples from 184 subjects for analysis in the breast clinic group. There were 203 subjects in the second control group; 29 of these women were excluded because they did not meet the frequencymatching criteria, and three samples could not be located, resulting in 171 samples for assay from subjects in the second group.

\section{Questionnaire}

Information on numerous known or suspected risk factors for breast cancer was collected via a questionnaire administered during an interview. These data included race/ethnicity, age, body build, educational attainment, alcohol and cigarette use, obstetric and gynaecological history, exogenous sex hormone exposure, personal and family history and past breast biopsy and mammography.

\section{Laboratory determinations}

The specimens available to us were frozen as whole blood and we were therefore unable to obtain either plasma or serum for analysis. Thus we performed a preliminary validation study in 19 volunteers to investigate the feasibility of using the archived samples of frozen, ethylenediamenetetra-acetic acid (EDTA)anticoagulated whole blood for the analysis of 25-D and 1,25-D.There was significant correlation between ranks of the values from whole blood and plasma: $r_{\mathrm{r}}=0.58$, $P<0.01$ for $1,25-\mathrm{D}$ and $r_{\mathrm{r}}=0.78, P<0.01$ for $25-\mathrm{D}$.

Briefly, the values of the active metabolite, 1,25-D, were on average $27 \%$ lower when determined in whole blood than when determined in plasma from volunteers. Values for 25-D were 50-60\% lower in whole blood. The lower values in the whole blood assays are probably related to the diluting effect of the haemolysed red cells. Levels of 25-D were further decreased because, unlike the 1,25-D analyses, values 
could not be corrected for individual sample recoveries with the 25-D assay technique. The coefficient of variation (CV) for interassay determinations of 1,25-D was greater in whole blood than in plasma, $14.8 \%$ versus $4.9 \%$, respectively. Similarly, the CV for intraassay determinations based on whole blood was greater than that for plasma, $11.2 \%$ versus $6.3 \%$. Interassay CV for 25-D was higher in whole blood than in plasma, $24.8 \%$ versus $17.1 \%$. Intra-assay CV for $25-\mathrm{D}$ was less in whole blood than in plasma, $6.8 \%$ versus $8.1 \%$.

The case-control study blood samples were stored at $-80^{\circ} \mathrm{C}$ from the beginning of collection in 1990 until the time of assay, an average of $3.99 \pm 0.52$ (mean $\pm \mathrm{SD}$ ) years. 1,25-D assays were done with a tritium-based calf thymus radioreceptor assay kit (INCSTAR, Stillwater, Minnesota) and the 25-D assays with a ${ }^{125}$ iodinebased radioimmunoassay kit (INCSTAR, Stillwater, Minnesota). These assays measure both ergocalciferol (vitamin $\mathrm{D}_{2}$ ) and cholecalciferol (vitamin $\mathrm{D}_{3}$ ). Equal numbers of samples were randomly selected from the three groups: cases, control group 1 and control group 2. Thus, each group contributed roughly one-third of the 40 study samples in each assay batch. Quality controls provided by INCSTAR and two to four samples of pooled plasma were included in each batch to monitor assay validity and reliability. Fourteen per cent of the analyses had to be redone because of technical difficulties such as problems with recovery. Laboratory personnel were blinded to case and control status.

\section{Statistical analysis}

We used standard methods for the analysis of casecontrol studies ${ }^{29}$ and employed SAS software for the statistical analyses ${ }^{30}$. Univariate distributions of the exposure variables and the relevant covariates guided decisions on coding of variables. Potential confounders were identified with bivariate analyses. We calculated odds ratios (ORs) using both $2 \times 2$ tables and unconditional logistic regression models. We included the matching variables in multivariate logistic regression models. The initial analysis considered 1,25-D in pmol ml ${ }^{-1}$ as a continuous variable; a second analysis used quartiles of 1,25-D with cut-off points defined by the distribution of 1,25-D among subjects in the relevant control group(s). We evaluated possible departure from linearity on the logistic scale by including squared terms in the models, and possible interactive effects by adding terms for the products of pairs of variables. $P$ values given are all two-sided.

\section{Results}

\section{Subject characteristics}

Four hundred and twenty-three (83\%) of the study subjects were non-Hispanic white and 74 (14\%) were black; there were eight Asian American, one native American and five Hispanic subjects. Women in the latter three minority categories were excluded from further analyses because their numbers were too small to provide meaningful results.

Black subjects were, on average, younger than white subjects and both black cases and black controls had higher body mass indices (BMIs) than whites (Table 1). Both black and white control subjects had characteristics usually associated with case status: they tended to have had fewer children and many had a history of benign breast disease.

We had originally intended to include the second control group in our breast cancer analyses. However, subjects in the second control group were not comparable to the case group or the primary control group either in month of blood drawing, length of sample storage time or clinic of origin. For these reasons, they were dropped from the breast cancer analyses but were included in the analyses of seasonality and race (Fig. 1 and Table 2).

\section{Seasonal variability}

An analysis of variance among all study subjects ( $n=$ 511) indicated that there were significant differences in the mean levels of 25-D by month of blood drawing $\left(F_{11,510}=2.18, P<0.015\right.$; Fig. 1a). Levels were lowest in the month of February and were highest in the month of July. By contrast, there were no differences in the mean levels of 1,25-D according to the month of blood drawing among all study subjects $\left(F_{11,510}=0.90, P=\right.$ 0.54; Fig. 1b). This was also true for groups analysed separately by race or case or control status (data not shown).

\section{Assay batch and sample storage}

Case sample storage time was shorter than control group sample storage time by approximately 74 days ( $4.06 \pm 0.68$ years vs. $4.26 \pm 0.36$ years, $P<0.01$ ). The logistic models for risk were adjusted for storage time with a continuous variable and adjusted for interbatch variability by an indicator variable for assay batch in multivariate logistic models.

\section{Vitamin D metabolites}

White cases had significantly lower levels of 1,25-D $\left(\mathrm{pmol} \mathrm{ml} \mathrm{l}^{-1}\right.$ ) than white controls; the difference was in the opposite direction for black subjects although the number of subjects was smaller. There were no casecontrol differences in mean values of 25-D for either group (Table 2). Looking only at control subjects, the mean levels of $1,25-\mathrm{D}$ were higher in blacks than in whites and the mean levels of 25-D were lower in blacks than in whites (Table 2).

The distributions of both 1,25-D and 25-D had a slight positive skew among all control subjects; this was 
Table 1 Comparison of selected characteristics by race and disease status

\begin{tabular}{|c|c|c|c|c|}
\hline & \multicolumn{2}{|c|}{ Black subjects } & \multicolumn{2}{|c|}{ White subjects } \\
\hline & Case $(n=21)$ & Control $(n=30)$ & Case $(n=131)$ & Control $(n=149)$ \\
\hline Age, years (mean (SD)) & $49.1(10.9)$ & $50.4(13.5)$ & $55.0(12.3)$ & $54.8(11.9)$ \\
\hline $\mathrm{BMI}, \mathrm{kg} \mathrm{m}^{-2}$ (mean (SD)) & $31.1(7.2)$ & $29.3(6.2)^{a}$ & $25.5(5.5)^{a}$ & $24.6(4.0)$ \\
\hline Menarche, years (mean (SD)) & $12.5(1.5)$ & $12.7(1.3)^{\mathrm{a}}$ & $12.7(1.3)^{\mathrm{b}}$ & $12.9(1.6)$ \\
\hline $\begin{array}{l}\text { Menopausal status } \\
\text { Pre (no. }(\%)) \\
\text { Post (no. }(\%))\end{array}$ & $\begin{array}{r}6(28.6) \\
15(71.4)\end{array}$ & $\begin{array}{l}10(33.3) \\
20(66.7)\end{array}$ & $\begin{array}{l}42(32.1) \\
89(67.9)\end{array}$ & $\begin{array}{r}47(31.5) \\
102(68.5)\end{array}$ \\
\hline Age at menopause, years (mean (SD)) & $43.1(9.1)$ & $43.05(9.26)^{\mathrm{a}}$ & $45.32(32.1)^{\mathrm{c}}$ & $43.4(8.0)^{\mathrm{a}}$ \\
\hline $\begin{array}{l}\text { Ever pregnant } \\
\text { Yes }(\text { no. }(\%)) \\
\text { No }(\text { no. }(\%))\end{array}$ & $\begin{array}{l}20(95.2) \\
1(4.8)\end{array}$ & $\begin{array}{r}24(80.0) \\
6(20.0)\end{array}$ & $\begin{array}{r}116(88.5) \\
15(11.5)\end{array}$ & $\begin{array}{r}128(85.9) \\
21(14.1)\end{array}$ \\
\hline Parity, no. of live children (mean (SD)) & $3.6(2.5)$ & $2.38(2.5)$ & $2.5(1.6)$ & $2.30(1.0)$ \\
\hline Age at first full-term pregnancy, years (mean (SD)) & $20.1(4.8)$ & $22.2(5.1)$ & $23.2(4.3)$ & $22.9(4.2)$ \\
\hline $\begin{array}{l}\text { Ever use oral contraceptives } \\
\text { Yes (no. }(\%)) \\
\text { No (no. }(\%))\end{array}$ & $\begin{array}{l}10(47.6) \\
11(52.4)\end{array}$ & $\begin{array}{l}19(63.3) \\
11(36.7)\end{array}$ & $\begin{array}{l}70(53.4) \\
61(46.6)\end{array}$ & $\begin{array}{l}69(46.3) \\
60(53.7)\end{array}$ \\
\hline $\begin{array}{l}\text { Ever use hormone replacement therapy } \\
\text { Yes (no. (\%)) } \\
\text { No (no. (\%)) }\end{array}$ & $\begin{array}{c}2(9.5) \\
19(90.5)\end{array}$ & $\begin{array}{r}8(26.7)^{\mathrm{a}} \\
21(70.0)\end{array}$ & $\begin{array}{l}53(40.5) \\
78(59.5)\end{array}$ & $\begin{array}{l}58(38.9)^{\mathrm{a}} \\
90(60.4)\end{array}$ \\
\hline $\begin{array}{l}\text { Ever smoke } \\
\text { Yes (no. (\%)) } \\
\text { No }(\text { no. }(\%))\end{array}$ & $\begin{array}{r}6(28.6) \\
15(71.4)\end{array}$ & $\begin{array}{l}13(43.3) \\
17(56.7)\end{array}$ & $\begin{array}{l}60(45.8) \\
71(54.2)\end{array}$ & $\begin{array}{l}62(41.6) \\
87(58.4)\end{array}$ \\
\hline $\begin{array}{l}\text { Drink alcohol } \\
\text { Ever (no. }(\%)) \\
\text { Never (no. (\%)) }\end{array}$ & $\begin{array}{r}7(33.3) \\
14(66.7)\end{array}$ & $\begin{array}{c}21(70.0) \star^{\star *} \\
9(30.0)\end{array}$ & $\begin{array}{l}69(52.7) \\
62(47.3)\end{array}$ & $\begin{array}{l}92(61.7) \\
57(38.3)\end{array}$ \\
\hline $\begin{array}{l}\text { Education } \\
\text { High school (no. (\%)) } \\
\text { High school, some college (no. (\%)) } \\
\text { College graduate + (no. (\%)) }\end{array}$ & $\begin{aligned} & 7(33.3) \\
& 10(47.6) \\
& 4(19.1)\end{aligned}$ & $\begin{array}{l}0 \\
18(60.0)_{s}^{*} \\
12(40.0)\end{array}$ & $\begin{array}{l}19(14.5) \\
72(54.9) \\
40(30.5)\end{array}$ & $\begin{array}{l}16(10.7) \\
80(53.7) \\
53(35.6)\end{array}$ \\
\hline $\begin{array}{l}\text { Breast cancer in a primary relative } \\
\text { Yes (no. }(\%)) \\
\text { No }(\text { no. }(\%))\end{array}$ & $\begin{array}{c}1(4.8) \\
20(95.2)\end{array}$ & $\begin{array}{c}2(6.7) \\
28(93.3)\end{array}$ & $\begin{array}{r}24(18.3) \\
107(81.7)\end{array}$ & $\begin{array}{r}30(20.1) \\
119(79.9)\end{array}$ \\
\hline $\begin{array}{l}\text { History of benign breast disease } \\
\text { Yes (no. }(\%)) \\
\text { No (no. }(\%))\end{array}$ & $\begin{array}{r}4(19.0) \\
17(80.9)\end{array}$ & $\begin{array}{r}9(30.0) \\
21(70.0)\end{array}$ & $\begin{array}{l}59(45.0) \\
71(54.2)^{a}\end{array}$ & $\begin{array}{l}89(59.7)_{s}^{*} \\
60(40.3)\end{array}$ \\
\hline
\end{tabular}

${ }_{1}$ data point missing.

${ }^{\mathrm{b}} 2$ data points missing.

${ }^{\circ} 8$ data points missing.

${ }^{*} \chi 2$ test (case vs. control), $P<0.05$.

${ }^{\star \star} \chi^{2}$ test (case vs. control), $P<0.01$.

also true for black and white controls analysed separately. Normalizing the distributions by taking the square root did not alter the results of the analyses so the results presented are those using the untransformed variables. There was no correlation between levels of 1,25-D and 25-D among all subjects as shown in the scatterplot of Fig. 2.

\section{Disease status}

The level of 1,25-D was related to risk in a linear fashion (on the logit scale); the level of 25-D was not related to risk of disease. Table 3 presents the unadjusted relationship between quartile of 1,25-D and breast cancer risk. Based on these data we estimate that women in the lowest quartile had a 3.2-fold increased risk compared to those in the highest quartile, when all cases were compared with all non-cases. For white women the estimated risk of breast cancer was 4.5-fold (95\% CI 2.2, 9.1) for the lowest quartile. Tests for trend using the Mantel extension test were significant at the $P<0.001$ level for the entire group and the white subgroup.

Black women did not have the same estimated risk of breast cancer associated with the lowest quartile of 1,25-D: OR 0.5 (95\% CI 0.1, 2.7). A stratified analysis by race with the median defined by the distribution of $1,25-\mathrm{D}$ in black and white controls $\left(51.6 \mathrm{pmol} \mathrm{ml} \mathrm{m}^{-1}\right.$ ) produced an OR for below median levels for blacks of $1.0(95 \%$ CI $0.4,2.7)$ and for whites of $2.2(95 \%$ CI $1.4,3.4)$; the Breslow-Day $\chi_{1 \mathrm{df}}^{2}$ was $2.1, P=0.15$, suggesting possible effect modification by race.

Adjustment for the matching variables, assay batch and sample storage time increased the estimated risk for the lowest quartile in white women to 5.3 (95\% CI 


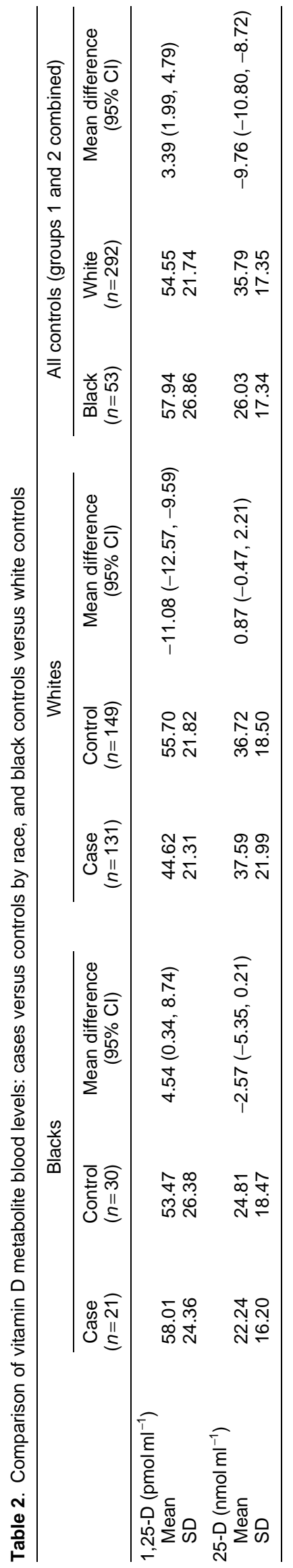

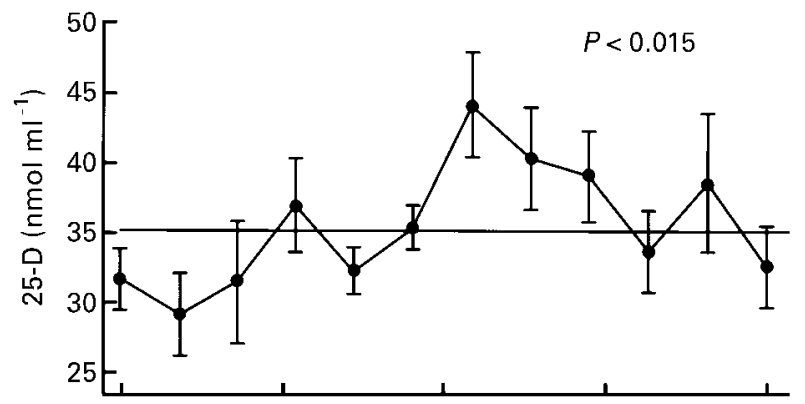

(a)

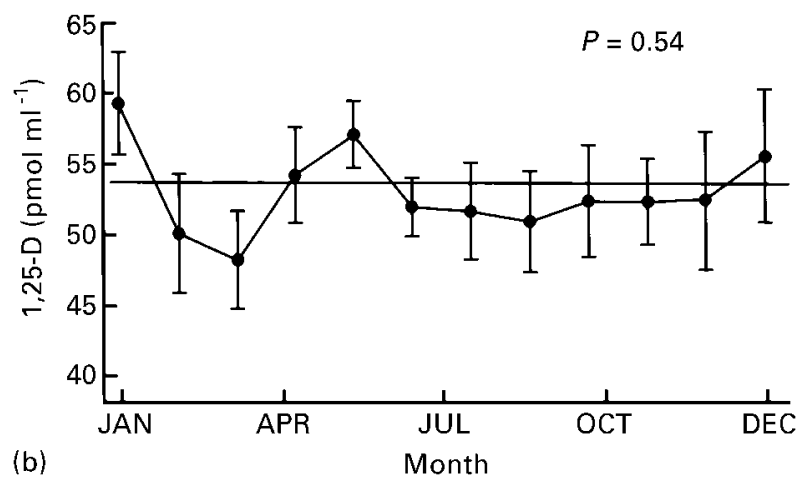

Fig. 1 Seasonal plot for (a) 25-D and (b) 1,25-D. Results are mean \pm SEM in $\mathrm{nmol} \mathrm{ml}^{-1}$ and $\mathrm{pmol} \mathrm{ml}^{-1}$, respectively. The statistical significance of the seasonal variation is given, as determined by one-way analysis of variance with months as factors $(n=511)$

$2.1,13.4$ ) (Table 3). Because of the possibility that more advanced disease could affect the blood level of 1,25-D, a subset analysis was carried out, omitting those women with lymph node metastases at the time of diagnosis $(n=26)$ from the multivariate logistic regression (Table 3). The estimated adjusted OR for the lowest quartile was 4.0 (95\% CI 1.5, 10.8).

We conducted a case-case comparison among white subjects to examine the relationship between stage of

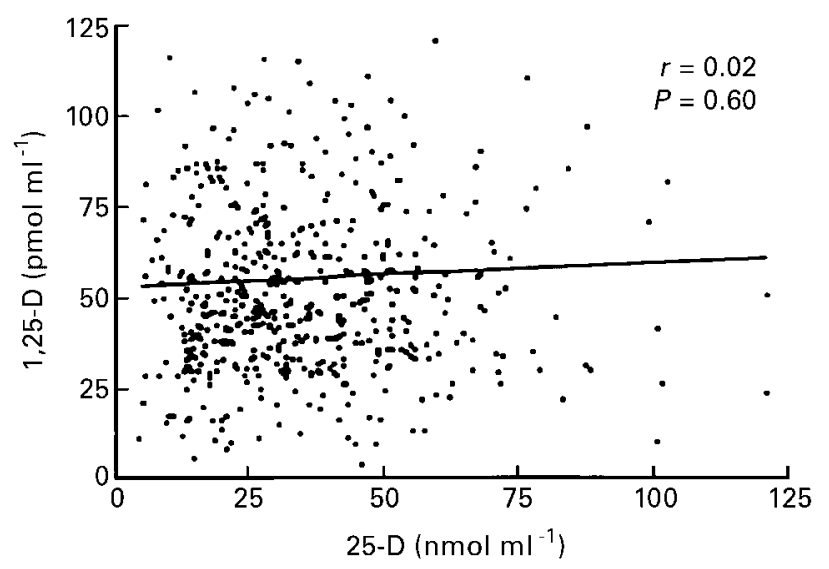

Fig. 2 Scatterplot of the relationship between circulating concentrations of $1,25-D$ and $25-D$. There was no correlation between metabolite levels $(n=511)$ 
Table 3 Odds ratios $(95 \% \mathrm{Cl})$ for the estimated risk of breast cancer associated with quartile of 1,25-D

\begin{tabular}{|c|c|c|c|c|c|c|}
\hline & \multirow[b]{2}{*}{ No. } & \multicolumn{4}{|c|}{ Quartile of $\left.1,25-\mathrm{D}(\mathrm{pmol} \mathrm{ml})^{-1}\right)^{*}$} & \multirow[b]{2}{*}{$P$ trend } \\
\hline & & 1 & 2 & 3 & 4 (ref) & \\
\hline \multicolumn{7}{|l|}{ Unadjusted odds ratios } \\
\hline All women & 331 & $3.2(1.7,6.0)$ & $1.8(1.0,3.4)$ & $1.5(0.8,2.9)$ & 1 & $<0.001$ \\
\hline Black women & 51 & $0.5(0.1,2.7)$ & $1.2(0.2,5.8)$ & $1.4(0.3,6.6)$ & 1 & 0.40 \\
\hline White women & 280 & $4.5(2.2,9.1)$ & $2.2(1.1,4.4)$ & $1.8(0.9,3.5)$ & 1 & $<0.001$ \\
\hline \multicolumn{7}{|l|}{ Adjusted odds ratios† } \\
\hline White women & 280 & $5.3(2.1,13.4)$ & $1.9(0.8,4.9)$ & $0.8(0.3,2.1)$ & 1 & $<0.001$ \\
\hline $\begin{array}{l}\text { Women with lymph node metastases at time } \\
\text { of diagnosis removed from the analysis }\end{array}$ & 254 & $4.0(1.5,10.8)$ & $1.4(0.5,3.9)$ & $0.5(0.2,1.4)$ & 1 & 0.002 \\
\hline
\end{tabular}

${ }^{*}$ Quartile ranges in pmol ml${ }^{-1}$ are based on the distribution of 1,25-D in the respective control group.

Quartiles: $\quad 1134.435$

All combined $\leqslant 34.61 \quad 34.62-48.41 \quad 48.42-63.55>63.55$

Black $\quad \leqslant 38.81 \quad 38.82-48.41 \quad 48.42-71.47 \quad>71.47$

White $\quad \leqslant 33.61 \quad 33.62-48.28 \quad 48.29-62.94 \quad>62.94$

† Adjusted for age, assay batch, month of blood draw, clinic and sample storage time.

disease and the level of 1,25-D. There were no differences in level of 1,25-D between those subjects with ductal carcinoma in situ (DCIS) and subjects with invasive ductal carcinoma. Similarly, among women with invasive ductal carcinoma there was no difference in 1,25-D levels between women with lymph node metastases at time of diagnosis and those without lymph node metastases.

The adjusted estimated risk, OR, associated with low versus high 1,25-D levels was higher for oestrogen and/ or progesterone receptor-positive breast cancer than receptor-negative breast cancer, 5.0 (95\% CI 2.3, 11.0) versus 1.1 (95\% CI 0.5, 3.0), respectively (Table 4). The Breslow-Day $\chi_{1 \mathrm{df}}^{2}$ was $5.9, P=0.02$, indicating that oestrogen/progesterone receptor status may modify the breast cancer risk associated with low 1,25-D.

\section{Relationship between previously described risk factors for breast cancer and vitamin $D$ metabolites}

We performed a stratified analysis with white subjects to investigate possible interactions between 1,25-D and selected covariates. An interaction was considered present if the Breslow-Day statistic for homogeneity of the ORs was significant at the 0.10 level $^{31}$. The estimated risk, OR, for breast cancer risk related to low versus high 1,25-D levels was greater for women above the age of 54 than for women aged 54 or younger, 4.7 $(95 \%$ CI $2.1,10.2)$ versus $1.5(95 \%$ CI $0.7,3.0), \chi^{2}{ }_{1 d f}=$ 4.7, $P=0.03$. Adjustment for matching variables, assay batch, sample storage time and clinic did not appreciably affect the ORs. There were no differences in estimated breast cancer risk associated with values of 1,25 -D below the median by menopausal status, value of BMI, level of $25-\mathrm{D}$, or use of hormone replacement therapy.

\section{Discussion}

The data in this work support the hypothesis that low levels of the active metabolite of vitamin D, 1,25-D, are associated with an increased risk of breast cancer. The estimated OR was greater than ORs previously reported for other 'established and probable' risk factors with the exception of a family history of breast cancer and a history of atypical hyperplasia, for both of which ORs of around 4.0 have been reported ${ }^{32}$. The vitamin D-breast cancer relationship was more pronounced in older than in younger women. Blot's original geographical description of breast cancer also suggested such a

Table 4 Evaluation of breast cancer risk associated with levels of 1,25-D below the median value by oestrogen and progesterone receptor status: white cases and controls

\begin{tabular}{|c|c|c|c|c|}
\hline \multirow[b]{2}{*}{ Group } & \multicolumn{2}{|c|}{$1,25-\mathrm{D}\left(\mathrm{pmol} \mathrm{m}{ }^{-1}\right)$} & \multirow{2}{*}{$\begin{array}{l}\text { Odds ratio } \\
(95 \% \mathrm{Cl})^{*}\end{array}$} & \multirow{2}{*}{$\begin{array}{l}\text { Adjusted odds ratio } \\
(95 \% \mathrm{Cl}) \dagger\end{array}$} \\
\hline & $\leqslant 53.38$ & $>53.38$ & & \\
\hline \multicolumn{5}{|c|}{ Receptor positiveł } \\
\hline Case & 44 & 9 & $4.8(2.2,10.6)$ & $5.0(2.3,11.0)$ \\
\hline Control & 75 & 74 & 1 & 1 \\
\hline \multicolumn{5}{|c|}{ Receptor negative§ } \\
\hline Case & 11 & 10 & $1.1(0.5,2.7)$ & $1.1(0.5,3.0)$ \\
\hline Control & 75 & 74 & 1 & 1 \\
\hline
\end{tabular}

${ }^{*}$ Breslow-Day: $\chi^{2}{ }_{1 \mathrm{df}}=5.9, P=0.02$.

$\dagger$ Adjusted for age, clinic and sample storage time.

$\ddagger$ Oestrogen and/or progesterone receptors present.

$\S$ Neither receptor present. 
relationship ${ }^{7}$. Breast cancer risk increases with age and while some studies have indicated that 1,25-D levels fall with age ${ }^{33}$, others report no difference in 1,25-D levels between healthy young and healthy elderly subjects ${ }^{34-37}$. Nevertheless, elderly women who are homebound, whether or not they are receiving supplementation, are at risk for vitamin $\mathrm{D}$ deficiency ${ }^{38}$.

There may be racial differences in the vitamin Dbreast cancer relationship. Lower levels of 1,25-D did not appear to be associated with breast cancer among black subjects, although they were clearly associated among whites. However, the effect of low 1,25-D was greater in older women among the white subjects, and the younger ages of the small sample of black women in our study may have prevented our seeing this effect in black subjects. The small number of black women in the study and the large confidence intervals around the estimated risks make it premature to draw conclusions about the association between low 1,25-D and risk of breast cancer in black women.

Levels of 1,25-D were similar in women with DCIS and invasive ductal carcinoma; this supports the assumption that early disease does not affect the levels of the active metabolite, but rather that the reduced blood level precedes the onset of breast cancer. There was no indication of a 'prognostic effect'; the magnitude of the estimated breast cancer risk was similar for subjects with DCIS, invasive ductal carcinoma without lymph node metastases, and invasive ductal carcinoma with lymph node metastases. Nevertheless, advanced disease with bone metastases and hypercalcaemia has been associated with depressed levels of $1,25-\mathrm{D}^{19}$.

The use of lysed whole blood rather than the preferred substrate of serum or plasma for analysis of the vitamin D metabolites was a potential weakness of this study. However, the validation study confirmed that the assay could be done validly and reliably with the substrate at hand, and the direction of the results with regard to racial differences in both 1,25-D and $25-\mathrm{D}$ is consistent with earlier work ${ }^{22-26}$. Furthermore, the maintenance of 1,25-D with age in healthy subjects is consistent with the findings of other researchers ${ }^{34-37}$. The seasonal variability detected for 25-D has also been reported by other investigators, as has the lack of seasonal variability for $1,25-\mathrm{D}^{33}$; this agreement with previous work further supports the validity of our data.

We did not have data on dietary intake of vitamin D, calcium, phosphorus, vitamin supplementation or sunlight exposure. Nevertheless, the blood level of 25-D is generally felt to be an accurate measure of vitamin D adequacy ${ }^{19}$. Since the majority of circulating hormone is produced by the action of ultraviolet $\mathrm{B}$ light on the skin, blood measurements of 25-D should reflect availability of vitamin $\mathrm{D}$ from all exogenous and endogenous sources. The lack of a difference in the blood level of 25-D between cases and controls supports the probability that both groups had adequate physiological amounts of the precursor hormone. However, selective decreases in dietary calcium and/ or phosphorus among the controls or selective increases among the cases relative to the controls, while unlikely, could have affected the 1,25-D levels ${ }^{39}$.

These were unusually similar cases and controls with respect to the usual breast cancer risk factors such as age at menarche, age at first pregnancy, BMI and age at menopause. This was probably a function of the selection process; the cases and controls were perceived by themselves and others to be at high risk for breast cancer and had attended specialized breast referral clinics. If vitamin $\mathrm{D}$ acts through pathways independent of the traditional risk factors, controlling for these traditional risk factors could increase the power of our study to detect 1,25-D effects ${ }^{40}$.

Previous studies have failed to detect a relationship between the precursor and the active metabolite ${ }^{41}$. Our results are similar in this regard. This observation is consistent with the possibility that vitamin D insufficiency per se is not related to disease, but rather there may be a mechanism involving inadequacy in the conversion of the precursor metabolite to the active metabolite ${ }^{33,42}$. The renal enzyme $1 \alpha$-hydroxylase that catalyses this conversion would be a likely site for such a mechanism. Activity of this enzyme may be genetically based. There is evidence that activity of the enzyme may decrease with age, thus placing older women at increased risk, particularly if their sources of vitamin $\mathrm{D}$ are inadequate ${ }^{42}$. Alternative mechanisms might relate to the vitamin D receptor and its levels in the breast ${ }^{43}$, or to specific genetic polymorphisms of the receptor, which may result in functional differences ${ }^{44,45}$.

Our data indicate that lower levels of 1,25-D are associated with an increased risk of breast cancer in white women. However, the vitamin D-breast cancer relationship in black and other minority women remains to be described. The data are consistent with the possibility that mechanisms other than vitamin D deficiency are responsible for the association between lower levels of 1,25-D and the risk of breast cancer. The findings need to be verified in a prospective study, as these issues have major implications for supplementation strategies. If protective effects of 1,25-D are shown, chemoprevention and/or chemotherapy using vitamin D analogues - synthetic compounds with effects on cellular growth and differentiation with minimized effect on calcium metabolism ${ }^{46-48}$ - would be an important area of investigation.

\section{Acknowledgements}

This research was supported by an intramural grant 
from the Lineberger Comprehensive Cancer Center, University of North Carolina at Chapel Hill, Chapel Hill, NC 27599, and by the Department of Defense DAMD 17-94-J-4344. The content of the information does not necessarily reflect the position or the policy of the government and no official endorsement should be inferred. We would like to thank David Ontjes for reviewing an earlier version of this manuscript.

\section{References}

1 DeLuca HF, Ostrem V. The relationship between the vitamin D system and cancer. Adv. Exp. Med. Biol. 1987; 206: 413-29.

2 Reichel H, Koeffler HP, Norman AW. The role of the vitamin D endocrine system in health and disease. N. Engl. J. Med. 1989; 320: 980-91.

3 Manoglas SC. Vitamin D and its relevance to cancer. AntiCancer Res. 1987; 7: 625-38.

4 Studzinski GP, Moore DC. Sunlight—can it prevent as well as cause cancer? Cancer Res. 1995; 55: 4014-22.

5 Gorham ED, Garland FC, Garland CF. Sunlight and breast cancer incidence in the USSR. Int. J. Epidemiol. 1990; 19: $820-4$.

6 Garland FC, Garland CF, Gorham ED, Young JF. Geographic variation in breast cancer mortality in the United States: a hypothesis involving exposure to solar radiation. Prev. Med. 1990; 19: 614-22.

7 Blot WJ, Fraumeni JF, Stone BJ. Geographic patterns of breast cancer in the United States. J. Natl. Cancer Inst. 1977; 59: $1407-11$.

8 Simard A, Vobecky J, Vobecky JS. Vitamin D deficiency and cancer of the breast: an unprovocative ecological hypothesis. Can. J. Public Health 1991; 82: 300-3.

9 Chouvet C, Vicard E, Devonec M, Saez S. 1,25-dihydroxyvitamin D3 inhibitory effect on the growth of two human breast cancer cell lines (MCF-7, BT-20). J. Steroid Biochem. 1986; 24: 373-6.

10 Frappart L, Falette N, Lefebvre MF, Bremond A, Vauzelle JL, Saez S. In vitro studies of effects of 1,25-dihydroxyvitamin D3 on the morphology of human breast cancer cell line BT-20. Differentiation 1989; 40: 63-9.

11 Welsh J. Induction of apoptosis in breast cancer cells in response to vitamin D and antiestrogens. Biochem. Cell Biol. 1994; 72: 537-47.

12 James SY, Mackay AG, Colston KW. Vitamin D derivatives in combination with 9-cis retinoic acid promote active cell death in breast cancer cells. J. Mol. Endocrinol. 1995; 14: 391-4.

13 Tsoukas CD, Provvedini DM, Manolagas SC. 1,25dihydroxyvitamin D3: a novel immunoregulatory hormone. Science 1984; 224(4656): 1438-40.

14 Reinhardt TA, Ramberg CF, Horst RL. Comparison of receptor binding, biological activity, and in vivo tracer kinetics for 1,25-dihydroxyvitamin D3, 1,25-dihydroxyvitamin D2, and its 24 epimer. Arch. Biochem. Biophys. 1989; 273: 6471.

15 Nemere I, Yoshimoto Y, Norman AW. Calcium transport in perfused duodena from normal chicks: enhancement within fourteen minutes of exposure to 1,25-dihydroxyvitamin D3. Endocrinology 1984; 115: 1476-83.

16 Krishnan AV, Feldman D. Stimulation of 1,25-dihydroxyvitamin D3 receptor gene expression in cultured cells by serum and growth factors. J. Bone Miner. Res. 1991; 6: 1099107.

17 Love RR, Mazess RB, Barden HS, et al. Effects of tamoxifen on bone mineral density in postmenopausal women with breast cancer. N. Engl. J. Med. 1992; 326: 852-6.
18 Holick MF. The use and interpretation of assays for vitamin D and its metabolites. J. Nutr. 1990; 120: 1464-9.

19 Mawer EB, Walls J, Howell A, Davies M, Ratcliffe WA Bundred NJ. Serum 1,25-dihydroxyvitamin D may be related inversely to disease activity in breast cancer with bone metastases. J. Clin. Endocrinol. Metab. 1997; 82: 118-22.

20 Elledge RM, Clark GM, Chamness GC, Osborne CK. Tumor biologic factors and breast cancer prognosis among white, Hispanic, and black women in the United States. J. Natl. Cancer Inst. 1994; 86: 705-12.

21 Abrams SA, O'Brien KO, Liang LK, Stuff JE. Differences in calcium absorption and kinetics between black and white girls aged 5-16 years. J. Bone Miner. Res. 1995; 10: 829-33.

22 Meier DE, Luckey MM, Wallenstein S, Clemens TL, Orwoll ES, Waslien CI. Calcium, vitamin D, and parathyroid hormone status in young white and black women: association with racial differences in bone mass. J. Clin. Endocrinol. Metab. 1991; 72: 703-10.

23 M'Buyamba-Kabangu JR, Fagard R, Lijnen P, Bouillon R, Lissens W, Amery A. Calcium, vitamin D-endocrine system, and parathyroid hormone in black and white males. Calcif. Tissue Int. 1987; 41: 70-4.

24 Reasner CA, Dunn JF, Fetchik DA, et al. Alteration of vitamin $\mathrm{D}$ metabolism in Mexican-Americans. J. Bone Miner. Res. 1990; 5: 13-17.

25 Bell NH, Greene A, Epstein S, Oexmann MJ, Shaw S, Shary J. Evidence for alteration of the vitamin D-endocrine system in blacks. J. Clin. Invest. 1985; 76: 470-3.

26 Loomis F. Skin-pigment regulation of vitamin D biosynthesis in man. Science 1967; 157: 501-6.

27 Hiatt RA, Krieger N, Lobaugh B, Drezner MK, Vogelman JH, Orentreich N. Prediagnostic serum vitamin D and breast cancer. J. Natl. Cancer Inst. 1998; 90: 461-3.

28 Garrett PA, Hulka BS, Kim YL, Farber RA. HRAS protooncogene polymorphism and breast cancer. Cancer Epidemiol. Biomark. Prev. 1993; 2: 131-8.

29 Hosmer DW, Lemeshow S. Applied Logistic Regression. New York: John Wiley \& Sons, 1989.

30 SAS Companion for the Microsoft Windows Environment, version 6. Cary, NC: SAS Institute Inc., 1993.

31 Breslow NE, Day NE. Statistical Methods in Cancer Research, Vol. I. The Analysis of Case-Control Studies Lyon: International Agency for Research on Cancer, 1980.

32 Harris JR, Lippman ME, Veronesi U, Willet W. Breast cancer N. Engl. J. Med. 1992; 327: 319-28.

33 Bouillon RA, Auwerx JH, Lissens WD, Pelemens WK Vitamin D status in the elderly: seasonal substrate deficiency causes 1,25-hydroxyvitamin cholecalciferol deficiency. Am. J. Clin. Nutr. 1987; 45: 755-63.

34 Sherman SS, Hollis BW, Tobin JD. Vitamin D status and related parameters in a healthy population: the effects of age, sex, and season. J. Clin. Endocrinol. Metab. 1990; 71 405-13.

35 Cantatore FP, Carrozzo M, Magle DM, D'Amore M, Pipitone V. Serum $1,25(\mathrm{OH}) 2 \mathrm{D}$ in the elderly and osteoporotic subjects from southern Italy. In: Norman AW, Schafer K, Grigoleit H-G, Herrath DV, eds. Vitamin D: Molecular, Cellular and Clinical Endocrinology. Proceedings of the Seventh Workshop on Vitamin D. New York: Walter de Gruyter \& Co., 1988; 897-8.

36 Halloran BP, Portale AA, Lonergan ET, Morris RC Jr. Production and metabolic clearance of 1,25-dihydroxyvitamin D in men: effect of advancing age. J. Clin. Endocrinol. Metab. 1990; 70: 318-23.

37 Tsai KS, Wahner HW, Offord KP, Melton LJ III, Kumar R, Riggs BL. Effect of aging on vitamin D stores and bone density in women. Calcif. Tissue Int. 1987; 40: 241-3.

38 Gloth FM III, Gundberg CM, Hollis BW, Haddad JG, Tobin JD. Vitamin D deficiency in homebound elderly persons. JAMA 1995; 274: 1683-6. 
39 Leaver DD, Trechsel U, Fleisch H. How is plasma $1,25(\mathrm{OH})_{2} \mathrm{D}_{3}$ concentration regulated by dietary calcium? In: Norman AW, Schafer K, Grigoleit H-G, Herrath DV, eds. Vitamin D: Molecular, Cellular and Clinical Endocrinology. Proceedings of the Seventh Workshop on Vitamin D. New York: Walter de Gruyter \& Co., 1988; 662-3.

40 Weiss NS, Liff JM. Accounting for the multicausal nature of disease in the design and analysis of epidemiologic studies. Am. J. Epidemiol. 1983; 117: 14-18.

41 Webb R, Pilbeam C, Hanafin N, Holick M. An evaluation of the relative contribution of exposure to sunlight and of diet to the circulating concentrations of 25-hydroxyvitamin D in an elderly nursing home population in Boston. Am. J. Clin. Nutr. 1990; 51: 1075-81.

42 Tsai KS, Heath H III, Kumar R, Riggs BL. Impaired vitamin D metabolism with aging in women. J. Clin. Invest. 1984; 73: 1668-72.

43 Colston KW, Berger U, Coombes RC. Possible role for vitamin D in controlling breast cell proliferation. Lancet 1989: i: 188-91.
44 Lieberman UA. Inborn errors in vitamin D metabolismtheir contributions to the understanding of vitamin $\mathrm{D}$ metabolism. In: Norman AW, Schafer K, Grigoleit H-G, Herrath DV, eds. Vitamin D: Molecular, Cellular and Clinical Endocrinology. Proceedings of the Seventh Workshop on Vitamin D. New York: Walter de Gruyter \& Co., 1988; 935-47.

45 Taylor JA, Hirvonen A, Watson M, Pittman G, Mohler JL, Bell DA. Association of prostate cancer with vitamin D receptor gene polymorphism. Cancer Res. 1996; 56: 410810.

46 Ikekawa N. Structures and biological activities of vitamin D metabolites and their analog. Med. Res. Rev. 1987; 7: 33366.

47 Matsumoto T. Cell differentiation and vitamin D. Nippon Naibunpi Gakki Zasshi 1992; 68(5): 526-37.

48 Mehta RG, Moriarty RM, Mehta RR, et al. Prevention of preneoplastic mammary lesion development by a novel vitamin D analogue, 1a-hydroxyvitamin D5. J. Natl. Cancer. Inst. 1997; 89: 212-18. 